\title{
DIFFERENTIAL FERTILITY BETWEEN WOMEN OF BLOOD GROUPS O AND $\mathrm{A}^{*}$ \\ BY
}

\author{
R. L. KIRK, M. KIRK, and N. S. STENHOUSE \\ From the Department of Zoology, University of Western Australia, and the Section of Mathematical Statistics, \\ C.S.I.R.O.
}

\section{INTRODUCTION}

The discovery of the $\mathrm{Rh}$ blood groups by Landsteiner and Wiener (1940), and the subsequent demonstration by Levine and others (1941) of their role in the aetiology of haemolytic disease of the newborn, has re-opened the problem of incompatibility between mother and foetus with respect to the A-B-O blood group antigens. Levine (1943) reviewed a number of family studies of the inheritance of blood groups and reached the conclusion that there was a significant deficiency of offspring in matings between mothers of blood group $\mathbf{O}$ and fathers of group $\mathbf{A}$, compared with those where the mother was of group $A$ and the father of group 0 .

More recently Waterhouse and Hogben (1947) have made a detailed analysis of twelve published studies in which the A-B-O blood groups of parents and children have been listed. Their samples were carefully selected on the basis of reliability of technique and randomness of the population investigated. A significant deficiency of children was found in the mating group O-mother : A-father compared with the reciprocal group, this deficiency being due entirely to the selective loss of A children of the group $O$ mothers. The effect was more marked at higher birth ranks. They concluded that provisional estimates suggest that A-B-O isoimmunization is responsible for the loss of about 25 per cent. of the A children expected from marriages between group $\mathbf{O}$ mothers and $\mathrm{A}$ fathers, or a loss of roughly 3 per cent. of all conceptions.

Race and Sanger (1950) point out the difficulty of reconciling a loss of this magnitude with the constancy of the frequencies for the A-B- and R genes over long periods of time, unless some compensatory mechanism is at work. At least two points require further study before our ideas on the possible nature of such compensatory mechanism can be clarified. These are:

(a) the provision of evidence of a collateral nature

* This investigation was aided by a grant from the Australian National Health and Medical Research Council. to substantiate the magnitude of the iso-immunization effect with respect to the agglutinogen $A$ reported by Waterhouse and Hogben (1947),

(b) a more detailed investigation of the relative fertility of group $\mathbf{O}$ women and group $\mathbf{A}$ women in a socially homogeneous population.

The present paper records the results of an analysis of the blood-type and previous pregnancy experience of women giving birth to children in a large maternity hospital during the years 1948 to 1951 . An effect of the magnitude of that reported by Waterhouse and Hogben for family studies should manifest itself in such a sample by a changing distribution of women of blood groups $\mathrm{O}$ and $\mathrm{A}$ with age and parity.

Since this work was started, Boorman (1950) and Bryce and others (1950) have published papers relating to blood group distributions in a series of mothers and infants, the data having been obtained from maternity hospitals in England and Australia. Bryce and others find a significant excess of group $A B$ among the mothers compared with their children, both for their Australian sample only, and for the Australian sample combined with Boorman's English sample. They suggest that some A and B genes may be replaced by especially fertile $\mathrm{AB}$ mothers. Where the data of these workers has been presented in sufficient detail comparisons will be made with results obtained in the present investigation.

\section{Methods of Collecting Data}

The data used in the present analysis was collected from the record cards of admissions to the King Edward Memorial Hospital, Perth. Selection was made for clinic patients; persons referred to the hospital by private doctors were rejected. In this way a comparatively socially-homogeneous group unselected for complications of pregnancy was made available for analysis. Details of previous pregnancy experience, together with information relating to age, outcome of present pregnancy, etc., is routinely listed on the cards.

The information relating to previous pregnancy experience, particularly miscarriages and to a lesser extent stillbirths, is likely to be misrepresented by the women concerned. We have assumed that the 
inaccuracies are distributed proportionately between the different groups. A-B-O and $\mathrm{Rh}$ blood group determinations are carried out on all clinic patients by workers in the Public Health Department Blood Group Laboratory attached to the hospital. A uniformity of testing technique is assured, and some of the patients are retested at monthly intervals during pregnancy.

The sample studied is a biased selection of women of the same age groups in the population in so far as all must be experiencing pregnancy when the records are entered. Those that miscarry after they have first attended the clinic, and who report their miscarriage, are appropriately listed.

\section{Analysis of Data}

During the 4-year period under review the sample was changing slightly in blood group distribution and in age composition. Table $I A$ gives the A-B-O blood group distribution for 6,121 mothers, Table $I B$ records the corresponding $\mathrm{Rh}$ frequency (anti- $D$ ).

Fig. 1.-Difference in average number of pregnancies per

TABLE I $A$

A-B-O BLOOD-GROUP DISTRIBUTION BY YEAR (Total Perth Sample)

\begin{tabular}{|c|c|c|c|c|c|c|c|}
\hline Year & . & . & 1948 & 1949 & 1950 & 1951 & $\underset{\text { Year s }}{\text { All }}$ \\
\hline \multirow{4}{*}{ Group } & $\mathbf{O}$ & $\begin{array}{l}\text { Number } \\
\text { Per cent. }\end{array}$ & $\begin{array}{c}437 \\
46 \cdot 0\end{array}$ & $\begin{array}{c}621 \\
43 \cdot 5\end{array}$ & $\begin{array}{c}816 \\
45 \cdot 2\end{array}$ & $\begin{array}{c}871 \\
45 \cdot 0\end{array}$ & $\begin{array}{l}2745 \\
44 \cdot 8\end{array}$ \\
\hline & $\mathbf{A}$ & $\begin{array}{l}\text { Number } \\
\text { Per cent. }\end{array}$ & $\begin{array}{c}407 \\
42 \cdot 9\end{array}$ & $\begin{array}{c}619 \\
43 \cdot 3\end{array}$ & $\begin{array}{c}756 \\
41 \cdot 8\end{array}$ & $\begin{array}{c}778 \\
40 \cdot 2\end{array}$ & $\begin{array}{l}2560 \\
41 \cdot 8\end{array}$ \\
\hline & B & $\begin{array}{l}\text { Number } \\
\text { Per cent. }\end{array}$ & $\begin{array}{l}84 \\
8 \cdot 8\end{array}$ & $\begin{array}{c}151 \\
10 \cdot 6\end{array}$ & $\begin{array}{c}178 \\
9.9\end{array}$ & $\begin{array}{c}216 \\
11 \cdot 2\end{array}$ & $\begin{array}{r}629 \\
10 \cdot 3\end{array}$ \\
\hline & $\mathbf{A B}$ & $\begin{array}{l}\text { Number } \\
\text { Per cent. }\end{array}$ & $\begin{array}{c}21 \\
2 \cdot 2\end{array}$ & $\begin{array}{c}38 \\
2 \cdot 6\end{array}$ & $\begin{array}{c}57 \\
3 \cdot 2\end{array}$ & $\begin{array}{c}71 \\
3 \cdot 7\end{array}$ & $\begin{array}{l}187 \\
3 \cdot 1\end{array}$ \\
\hline$\underset{\text { All }}{\text { Groups }}$ & & $\begin{array}{l}\text { Number } \\
\text { Per cent. }\end{array}$ & $\begin{array}{c}949 \\
99 \cdot 9\end{array}$ & $\begin{array}{c}1429 \\
100 \cdot 0\end{array}$ & $\begin{array}{c}1807 \\
100 \cdot 1\end{array}$ & $\begin{array}{c}1936 \\
100 \cdot 1\end{array}$ & $\begin{array}{r}6121 \\
100 \cdot 0\end{array}$ \\
\hline
\end{tabular}

TABLE IB

Rh BLOOD-GROUP DISTRIBUTION BY YEAR (Total Perth Sample)

\begin{tabular}{|c|c|c|c|c|c|c|c|}
\hline Year & .. & .. & 1948 & 1949 & 1950 & 1951 & $\begin{array}{c}\text { All } \\
\text { Years }\end{array}$ \\
\hline \multirow{2}{*}{ Group } & $\mathbf{R h}+$ & $\begin{array}{l}\text { Number } \\
\text { Per cent. }\end{array}$ & $\begin{array}{l}816 \\
86.0\end{array}$ & $\begin{array}{l}1,185 \\
82 \cdot 9\end{array}$ & $\begin{array}{l}1,502 \\
83 \cdot 1\end{array}$ & $\begin{array}{l}1,618 \\
83 \cdot 6\end{array}$ & $\begin{array}{l}5,121 \\
83 \cdot 7\end{array}$ \\
\hline & $\mathbf{R h}-$ & $\begin{array}{l}\text { Number } \\
\text { Per cent. }\end{array}$ & $\begin{array}{l}133 \\
14 \cdot 0 \\
\end{array}$ & $\begin{array}{r}244 \\
17 \cdot 1 \\
\end{array}$ & $\begin{array}{r}305 \\
16.9 \\
\end{array}$ & $\begin{array}{r}318 \\
16.4\end{array}$ & $\begin{array}{l}1,000 \\
16 \cdot 3 \\
\end{array}$ \\
\hline Total & & $\begin{array}{l}\text { Number } \\
\text { Per cent. }\end{array}$ & $\begin{array}{c}949 \\
100 \cdot 0\end{array}$ & $\begin{array}{r}1,429 \\
100 \cdot 0\end{array}$ & $\begin{array}{c}1,807 \\
100 \cdot 0\end{array}$ & $\begin{array}{c}1,936 \\
100 \cdot 0\end{array}$ & $\begin{array}{r}6,121 \\
100 \cdot 0\end{array}$ \\
\hline
\end{tabular}

The frequency of Group $B$ and AB have tended to increase, and although the analysis of the complete table does not indicate a significant deviation from expectation, a comparison of the combined group O-A with the combined group $B$ and $A B$ frequencies suggests that this trend is a real one $\left(\chi^{2}=8 \cdot 137,0.02<P<0.05\right)$. It is also clear that the change in the age composition of the 4-year samples in Table II, with a proportionate decrease in the under-20 age group and an increase in the 26-30 age group is also significant $\left(\chi^{2}=\right.$ $30 \cdot 954,0.001<P<0.01$ ).

TABLE II

AGE-GROUP DISTRIBUTION BY YEAR (Total Perth Sample)

\begin{tabular}{|c|c|c|c|c|c|c|c|}
\hline Year & $\cdots$ & $\ldots$ & 1948 & 1949 & 1950 & 1951 & $\underset{\text { Years }}{\text { All }}$ \\
\hline \multirow{6}{*}{$\begin{array}{c}\text { Age } \\
\text { Group }\end{array}$} & $\begin{array}{l}20 \text { and } \\
\text { under }\end{array}$ & $\begin{array}{l}\text { Number } \\
\text { Per cent. }\end{array}$ & $\begin{array}{c}213 \\
22 \cdot 4\end{array}$ & $\begin{array}{c}299 \\
20 \cdot 9\end{array}$ & $\begin{array}{c}351 \\
19 \cdot 4\end{array}$ & $\begin{array}{c}354 \\
18 \cdot 3\end{array}$ & $\begin{array}{l}1,217 \\
19 \cdot 9\end{array}$ \\
\hline & $21-25$ & $\begin{array}{l}\text { Number } \\
\text { Per cent. }\end{array}$ & $\begin{array}{c}349 \\
36 \cdot 8\end{array}$ & $\begin{array}{c}501 \\
35 \cdot 1\end{array}$ & $\begin{array}{c}653 \\
36 \cdot 9\end{array}$ & $\begin{array}{c}692 \\
35 \cdot 7\end{array}$ & $\begin{array}{l}2,195 \\
35 \cdot 9\end{array}$ \\
\hline & $26-30$ & $\begin{array}{l}\text { Number } \\
\text { Per cent. }\end{array}$ & $\begin{array}{c}183 \\
19 \cdot 3\end{array}$ & $\begin{array}{c}322 \\
22 \cdot 6\end{array}$ & $\begin{array}{c}431 \\
23 \cdot 8\end{array}$ & $\begin{array}{c}503 \\
26 \cdot 0\end{array}$ & $\begin{array}{r}1,439 \\
23 \cdot 5\end{array}$ \\
\hline & $31-35$ & $\begin{array}{l}\text { Number } \\
\text { Per cent. }\end{array}$ & $\begin{array}{c}113 \\
11 \cdot 9\end{array}$ & $\begin{array}{c}176 \\
12 \cdot 3\end{array}$ & $\begin{array}{c}221 \\
12 \cdot 2\end{array}$ & $\begin{array}{c}211 \\
10 \cdot 9\end{array}$ & $\begin{array}{r}721 \\
11 \cdot 8\end{array}$ \\
\hline & $36-40$ & $\begin{array}{l}\text { Number } \\
\text { Per cent. }\end{array}$ & $\begin{array}{c}69 \\
7 \cdot 3\end{array}$ & $\begin{array}{c}112 \\
7 \cdot 8\end{array}$ & $\begin{array}{c}116 \\
6 \cdot 4\end{array}$ & $\begin{array}{c}151 \\
7 \cdot 8\end{array}$ & $\begin{array}{l}448 \\
7 \cdot 3\end{array}$ \\
\hline & $\begin{array}{c}\text { Over } \\
40\end{array}$ & $\begin{array}{l}\text { Number } \\
\text { Per cent. }\end{array}$ & $\begin{array}{c}22 \\
2 \cdot 3\end{array}$ & $\begin{array}{c}19 \\
1 \cdot 3\end{array}$ & $\begin{array}{c}35 \\
1 \cdot 9\end{array}$ & $\begin{array}{c}25 \\
1 \cdot 3\end{array}$ & $\begin{array}{c}101 \\
1 \cdot 7\end{array}$ \\
\hline & $\begin{array}{c}\text { All } \\
\text { Ages }\end{array}$ & $\begin{array}{l}\text { Number } \\
\text { Per cent. }\end{array}$ & $\begin{array}{c}949 \\
100 \cdot 0\end{array}$ & $\begin{array}{l}1,429 \\
100 \cdot 0\end{array}$ & $\begin{array}{r}1,807 \\
99 \cdot 9\end{array}$ & $\begin{array}{l}1,936 \\
100 \cdot 0\end{array}$ & $\begin{array}{r}6,121 \\
100 \cdot 1\end{array}$ \\
\hline
\end{tabular}

The change in the frequency of group $B$ and $A B$ suggested that recent arrivals in Australia from countries with relatively higher frequencies of group B than for typical English and Australian populations were making a significant contribution to this effect. Accordingly, we have differentiated the sample on the basis of name (cf. Hart, 1944; Roberts, 1948) into two groups:
(a) of English name, and
(b) of non-English name.

The second group comprises people drawn from Eastern, Central, and Southern Europe in the majority with a fairly substantial number of Dutch migrants. The country of origin of these people all have frequencies for the B-gene higher than that in Great Britain. (Wiener, 1943.)

The tendency for the frequency of $\mathrm{B}$ and $\mathrm{AB}$ to increase in recent years in the total sample disappears if women of English name only are included. The frequency for A-O combinations against $\mathrm{B}-\mathrm{AB}$ in this group (Table III $A$ ) shows no heterogeneity $\left(\chi^{2}=3 \cdot 751,0 \cdot 30>P>0 \cdot 20\right)$. Further, the heterogeneity of the sample with regard to age groups is considerably reduced if women of non-English name are removed, although there is still a slight 
TABLE III $A$

BLOOD-GROUP DISTRIBUTION OF WOMEN OF ENGLISH NAME BY YEAR

\begin{tabular}{|c|c|c|c|c|c|c|c|}
\hline Year & & & 1948 & 1949 & 1950 & 1951 & $\begin{array}{c}\text { All } \\
\text { Years }\end{array}$ \\
\hline \multirow{4}{*}{ Group } & 0 & $\begin{array}{l}\text { Number } \\
\text { Per cent. }\end{array}$ & $\begin{array}{c}388 \\
47 \cdot 0\end{array}$ & $\begin{array}{c}558 \\
43 \cdot 9\end{array}$ & $\begin{array}{c}665 \\
45 \cdot 7\end{array}$ & $\begin{array}{l}716 \\
47 \cdot 0\end{array}$ & $\begin{array}{r}2,327 \\
45 \cdot 8\end{array}$ \\
\hline & $\overline{\mathbf{A}}$ & $\begin{array}{l}\text { Number } \\
\text { Per cent. }\end{array}$ & $\begin{array}{l}351 \\
42 \cdot 5\end{array}$ & $\begin{array}{c}5599 \\
44.0\end{array}$ & $\begin{array}{c}609 \\
41 \cdot 8\end{array}$ & $\begin{array}{l}6007 \\
39 \cdot 8\end{array}$ & $\begin{array}{l}2,126 \\
41.9\end{array}$ \\
\hline & B & $\begin{array}{l}\text { Number } \\
\text { Per cent. }\end{array}$ & $\begin{array}{c}72 \\
8 \cdot 7\end{array}$ & $\begin{array}{l}123 \\
9 \cdot 7\end{array}$ & $\begin{array}{l}143 \\
9 \cdot 8\end{array}$ & $\begin{array}{c}156 \\
10 \cdot 2\end{array}$ & $\begin{array}{l}494 \\
9 \cdot 7\end{array}$ \\
\hline & $\mathbf{A B}$ & $\begin{array}{l}\text { Number } \\
\text { Per cent. }\end{array}$ & $\begin{array}{l}15 \\
1 \cdot 8\end{array}$ & $\begin{array}{c}31 \\
2 \cdot 4\end{array}$ & $\begin{array}{c}39 \\
2 \cdot 7\end{array}$ & $\begin{array}{l}46 \\
3 \cdot 0\end{array}$ & $\begin{array}{l}131 \\
2.6\end{array}$ \\
\hline \multicolumn{2}{|l|}{$\overline{\text { All }}$} & $\begin{array}{l}\text { Number } \\
\text { Per cent. }\end{array}$ & \begin{tabular}{|c|}
826 \\
$100 \cdot 0$
\end{tabular} & $\begin{array}{l}1,271 \\
100 \cdot 0\end{array}$ & $\begin{array}{l}1,456 \\
100 \cdot 0\end{array}$ & $\begin{array}{l}1,525 \\
100 \cdot 0\end{array}$ & $\begin{array}{r}5,078 \\
100 \cdot 0\end{array}$ \\
\hline
\end{tabular}

TABLE III $B$

AGE-GROUP DISTRIBUTION OF WOMEN OF ENGLISH NAME BY YEAR

\begin{tabular}{|c|c|c|c|c|c|c|c|}
\hline Year & .. & . & 1948 & 1949 & 1950 & 1951 & $\begin{array}{c}\text { All } \\
\text { Years }\end{array}$ \\
\hline \multirow{6}{*}{$\begin{array}{c}\text { Age } \\
\text { Group }\end{array}$} & $\begin{array}{l}20 \text { and } \\
\text { under }\end{array}$ & $\begin{array}{l}\text { Number } \\
\text { Per cent. }\end{array}$ & $\begin{array}{c}190 \\
23 \cdot 0\end{array}$ & $\begin{array}{c}275 \\
21 \cdot 6\end{array}$ & $\begin{array}{c}296 \\
20 \cdot 3\end{array}$ & $\begin{array}{c}314 \\
20 \cdot 6\end{array}$ & $\begin{array}{r}1,075 \\
21 \cdot 2\end{array}$ \\
\hline & $21-25$ & $\begin{array}{l}\text { Number } \\
\text { Per cent. }\end{array}$ & $\begin{array}{c}300 \\
36 \cdot 3\end{array}$ & $\begin{array}{c}435 \\
34 \cdot 2\end{array}$ & $\begin{array}{c}525 \\
36 \cdot 1\end{array}$ & $\begin{array}{c}545 \\
35 \cdot 7\end{array}$ & $\begin{array}{r}1,805 \\
35 \cdot 5\end{array}$ \\
\hline & $26-30$ & $\begin{array}{l}\text { Number } \\
\text { Per cent. }\end{array}$ & $\begin{array}{l}162 \\
19 \cdot 6\end{array}$ & $\begin{array}{r}291 \\
22 \cdot 9\end{array}$ & $\begin{array}{c}329 \\
22 \cdot 6\end{array}$ & $\begin{array}{c}370 \\
24 \cdot 3\end{array}$ & $\begin{array}{l}1,152 \\
22 \cdot 7\end{array}$ \\
\hline & $31-35$ & $\begin{array}{l}\text { Number } \\
\text { Per cent. }\end{array}$ & $\begin{array}{r}95 \\
11 \cdot 5\end{array}$ & $\begin{array}{l}157 \\
12 \cdot 4\end{array}$ & $\begin{array}{l}183 \\
12 \cdot 6\end{array}$ & $\begin{array}{l}160 \\
10.5\end{array}$ & $\begin{array}{r}595 \\
11 \cdot 7\end{array}$ \\
\hline & $36-40$ & $\begin{array}{l}\text { Number } \\
\text { Per cent. }\end{array}$ & $\begin{array}{c}60 \\
7 \cdot 3\end{array}$ & $\begin{array}{l}98 \\
7 \cdot 7\end{array}$ & $\begin{array}{l}91 \\
6 \cdot 2\end{array}$ & $\begin{array}{l}116 \\
7 \cdot 6\end{array}$ & $\begin{array}{r}365 \\
7 \cdot 2\end{array}$ \\
\hline & $\begin{array}{c}\text { Over } \\
40\end{array}$ & $\begin{array}{l}\text { Number } \\
\text { Per cent. }\end{array}$ & $\begin{array}{l}19 \\
2 \cdot 3\end{array}$ & $\begin{array}{l}15 \\
1 \cdot 2\end{array}$ & $\begin{array}{l}32 \\
2 \cdot 2\end{array}$ & $\begin{array}{l}20 \\
1 \cdot 3\end{array}$ & $\begin{array}{r}86 \\
1 \cdot 7\end{array}$ \\
\hline & $\begin{array}{l}\text { All } \\
\text { Ages }\end{array}$ & $\begin{array}{l}\text { Number } \\
\text { Per cent. }\end{array}$ & $\begin{array}{r}826 \\
100 \cdot 0\end{array}$ & $\begin{array}{l}1,271 \\
100 \cdot 0\end{array}$ & $\begin{array}{l}1,456 \\
100 \cdot 0\end{array}$ & $\begin{array}{l}1,525 \\
100 \cdot 0\end{array}$ & $\begin{array}{r}5,078 \\
100 \cdot 0\end{array}$ \\
\hline
\end{tabular}

tendency for the 1950 and 1951 sample of women of English name to contain a relatively higher proportion of women aged 21-30 than in the previous 2 years (Table III $B$ ). It seems reasonable to assume, therefore, that the women of English name are a socially homogeneous population with respect to their A-B-O blood group distributions, and at present there is no reason to suppose that socio-economic conditions will affect the childbearing capacity of women in one blood group compared with those in another.

If, however, the figures for the average number of pregnancies experienced per woman in group $\mathbf{O}$ are compared with those for women in group A an interesting difference between the two groups emerges. Tables IV $A$ and IV $B$ (overleaf) record the pregnancy rank of Rh-positive women of English name in blood groups $\mathbf{O}$ and $\mathrm{A}$. Although the overall pregnancy experience of women in the two groups is almost identical (being slightly, but not significantly, higher for women of group A), there is a marked deficiency of pregnancies experienced by women of group $\mathrm{O}$ between 25 and 35 , with a tendency toward a marked excess of pregnancies in the same group for women above the age of 35 . Orthogonal polynomials were fitted to this series of differences in average number of pregnancies between women in group $\mathbf{O}$ and $\mathbf{A}$ for each year of age from 16 to 40 (see Figure). The result shows that the observed trend is highly significant, the bulk of the variance being attributed to the binomial expression.

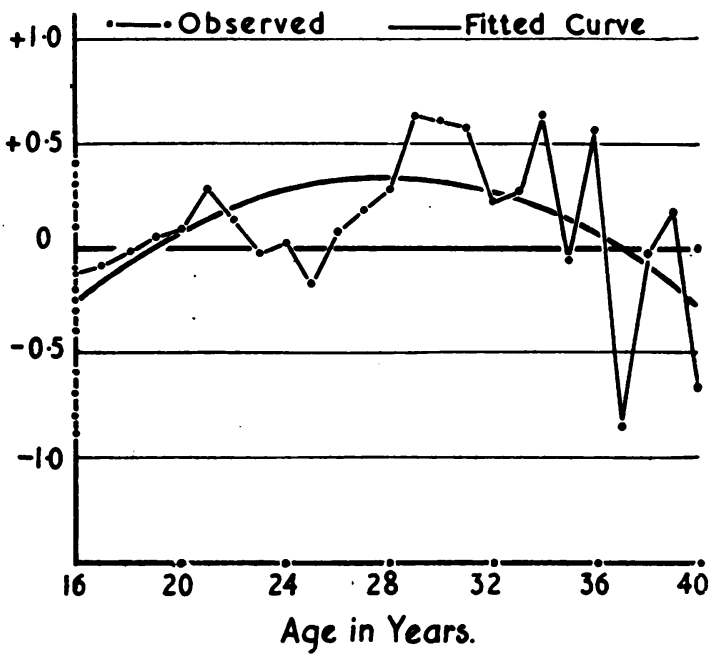
FIGURE-Difference in average number of pregnancies per
woman, $A-O$

The same trend is observable in the extremely heterogeneous group of women of non-English name (Table V). A polynomial analysis by each year of age of the Rh-positive women in the total sample again yields a highly significant result.

TABLE V

AVERAGE NUMBER OF PREGNANCIES IN Rh-POSITIVE WOMEN

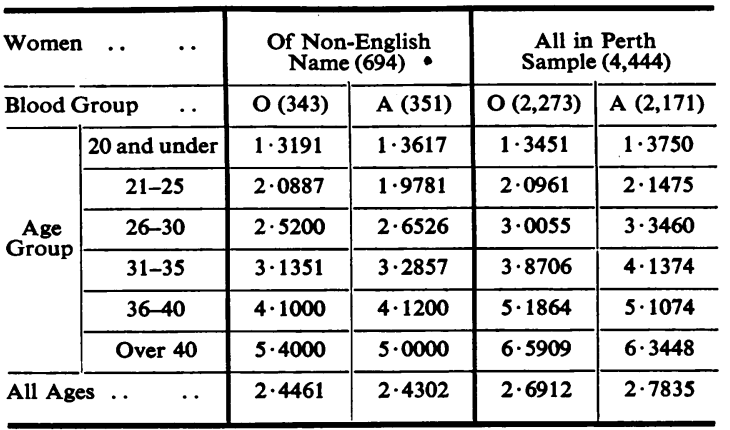


TABLE IV $A$

NUMBER OF PREGNANCIES EXPERIENCED BY Rh-POSITIVE GROUP O WOMEN OF ENGLISH NAME

\begin{tabular}{|c|c|c|c|c|c|c|c|c|c|c|c|c|c|c|}
\hline \multirow{2}{*}{ Age } & \multicolumn{11}{|c|}{ Number of Pregnancies } & \multirow{2}{*}{$\begin{array}{c}\text { Total } \\
\text { Women }\end{array}$} & \multirow{2}{*}{$\begin{array}{c}\text { Total } \\
\text { Preg- } \\
\text { nancies } \\
\end{array}$} & \multirow{2}{*}{$\begin{array}{c}\text { Average } \\
\text { Pregnancies } \\
\text { per Woman }\end{array}$} \\
\hline & 1 & 2 & 3 & 4 & 5 & 6 & 7 & 8 & 9 & 10 & $10+$ & & & \\
\hline Total (16 and under) & 18 & - & 1 & & & & & & & & & 19 & 21 & $1 \cdot 1053$ \\
\hline 17 & 30 & 6 & & & & & & & & & & 36 & 42 & $1 \cdot 1667$ \\
\hline 18 & 69 & 13 & 2 & & & & & & & & & 84 & 101 & $1 \cdot 2024$ \\
\hline 19 & 85 & 32 & 5 & 2 & & & & & & & & 124 & 172 & $1 \cdot 3871$ \\
\hline 20 & 88 & 43 & 9 & 1 & 1 & & & & & & & 142 & 210 & $1 \cdot 4789$ \\
\hline Total (20 and under) & 290 & 94 & 17 & 3 & 1 & & & & & & & 405 & 546 & $1 \cdot 3481$ \\
\hline 21 & 81 & 50 & 16 & 2 & - & - & 1 & & & & & 150 & 244 & $1 \cdot 6267$ \\
\hline 22 & 57 & 61 & 25 & 5 & 2 & 1 & - & & & & & 151 & 290. & $1 \cdot 9205$ \\
\hline 23 & 33 & 54 & 31 & 11 & 1 & - & - & & & & & 130 & 283 & $2 \cdot 1769$ \\
\hline 24 & 24 & 51 & 35 & 11 & 4 & 1 & - & & & & & 126 & 301 & $2 \cdot 3889$ \\
\hline 25 & 20 & 46 & 33 & 16 & 3 & 2 & - & & & & & 120 & 302 & $2 \cdot 5167$ \\
\hline Total (21-25) $\ldots$ & 215 & 262 & 140 & 45 & 10 & 4 & 1 & & & & & 677 & 1,420 & $2 \cdot 0975$ \\
\hline 26 & 15 & 34 & 41 & 12 & 6 & 3 & 2 & & & & & 113 & 316 & $2 \cdot 7965$ \\
\hline 27 & 13 & 39 & 26 & 21. & 11 & - & 3 & & & & & 113 & 329 & $2 \cdot 9115$ \\
\hline 28 & 12 & 16 & 28 & 15 & 10 & 5 & 1 & & & & & 87 & 275 & $3 \cdot 1609$ \\
\hline 29 & 8 & 14 & 19 & 18 & 8 & 4 & 2 & 2 & & & & 75 & 259 & $3 \cdot 4533$ \\
\hline 30 & 8 & 12 & 8 & 9 & 10 & 4 & 3 & 1 & 1 & & & 56 & 204 & $3 \cdot 6429$ \\
\hline Total $(26-30) \quad \ldots$ & 56 & 115 & 122 & 75 & 45 & 16 & 11 & 3 & 1 & & & 444 & 1,383 & $3 \cdot 1149$ \\
\hline 31 & 5 & 5 & 9 & 9 & 12 & 2 & 1 & - & - & & & 43 & 157 & $3 \cdot 6512$ \\
\hline 32 & 4 & 14 & 9 & 11 & 5 & 4 & 4 & - & 1 & & & 52 & 189 & $3 \cdot 6346$ \\
\hline 33 & 3 & 5 & 17 & 10 & 5 & 4 & 3 & 3 & 1 & & & 51 & 207 & $4 \cdot 0588$ \\
\hline 34 & 1 & 6 & 8 & 7 & 8 & 3 & 2 & 1 & 1 & & & 37 & 154 & $4 \cdot 1622$ \\
\hline 35 & 2 & 4 & 4 & 7 & 7 & 3 & 3 & 5 & - & & & 35 & 164 & $4 \cdot 6857$ \\
\hline Total $(31-35) \quad \ldots$ & 15 & 34 & 47 & 44 & 37 & 16 & 13 & 9 & 3 & & & 218 & 871 & $3 \cdot 9954$ \\
\hline 36 & 2 & 4 & 11 & 10 & 4 & 7 & 5 & - & 4 & & & 47 & 216 & $4 \cdot 5957$ \\
\hline 37 & - & 1 & 1 & 3 & 6 & 6 & 1 & 2 & 2 & - & 1 & 23 & 136 & $5 \cdot 9130$ \\
\hline 38 & 1 & 3 & 3 & 7 & 2 & 3 & 2 & 3 & 1 & 3 & - & 28 & 149 & $5 \cdot 3214$ \\
\hline 39 & - & 2 & 4 & 4 & 2 & 3 & 1 & 3 & 2 & 2 & 2 & 25 & 152 & $6 \cdot 0800$ \\
\hline 40 & 一 & 2 & 4 & 1 & 6 & 1 & 3 & 3 & 1 & 2 & 1 & 24 & 142 & $5 \cdot 9167$ \\
\hline Total $(36-40) \quad \ldots$ & 3 & 12 & 23 & 25 & 20 & 20 & 12 & 11 & 10 & 7 & 4 & 147 & 795 & $5 \cdot 4082$ \\
\hline Total (Over 40) & 1 & - & 3 & 6 & 8 & 4 & 2 & 3 & 3 & 6 & 3 & 39 & 263 & $6 \cdot 7436$ \\
\hline Grand Total $\ldots$ & 580 & 517 & 352 & 198 & 121 & 60 & 39 & 26 & 17 & 13 & 7 & 1,930 & 5,278 & $2 \cdot 7347$ \\
\hline
\end{tabular}

It would be expected that, if women of a particular age group are experiencing fewer pregnancies if they belong to group $O$ than if they belong to group A, they will be underrepresented in a maternity hospital sample for those ages compared with a sample of all women. In the present series this is clearly the case. Table VI $A$ (overleaf) records the ratio of $\mathrm{O}: \mathrm{A} \mathrm{Rh}$-positive women in 5-year age groups. Table VI $B$ (overleaf), based on Boorman (1950), reveals the same trend in this smaller sample. A poly- nomial analysis by each year of age from 16-40 for women of English name in our own series indicates that the trend is significant. Under the age of 25 , group $O$ women appear in the sample in the same proportion as they do in the total sample. Between 25 and 35 , group $O$ is considerably underrepresented, and over 35 an increase in the proportion of group $O$ takes place which compensates for the deficiency in the preceding 10-year period. Both in our own series and in Boorman's a notable feature is the 
TABLE IVB

NUMBER OF PREGNANCIES EXPERIENCED BY Rh-POSITIVE GROUP A WOMEN OF ENGLISH NAME

\begin{tabular}{|c|c|c|c|c|c|c|c|c|c|c|c|c|c|c|}
\hline \multirow{2}{*}{ Age } & \multicolumn{11}{|c|}{ Number of Pregnancies } & \multirow{2}{*}{$\begin{array}{c}\text { Total } \\
\text { Women }\end{array}$} & \multirow{2}{*}{$\begin{array}{c}\text { Total } \\
\text { Preg- } \\
\text { nancies }\end{array}$} & \multirow{2}{*}{$\begin{array}{l}\text { Average } \\
\text { Pregnancies } \\
\text { per Woman }\end{array}$} \\
\hline & 1 & 2 & 3 & 4 & 5 & 6 & 7 & 8 & 9 & 10 & $10+$ & & & \\
\hline Total (16 and under) & 11 & & & & & & & & & & & 11 & 11 & $1 \cdot 0000$ \\
\hline 17 & 36 & 3 & & & & & & & & & & 39 & 42 & $1 \cdot 0769$ \\
\hline 18 & 66 & 13 & 1 & & & & & & & & & 80 & 95 & $1 \cdot 1875$ \\
\hline 19 & 72 & 44 & 4 & & & & & & & & & 120 & 172 & $1 \cdot 4333$ \\
\hline 20 & 73 & 50 & 11 & 1 & & & & & & & & 135 & 210 & 1.5556 \\
\hline Total (20 and under) & 258 & 110 & 16 & 1 & & & & & & & & 385 & 530 & $1 \cdot 3766$ \\
\hline 21 & 51 & 54 & 26 & 4 & - & 1 & & & & & & 136 & 259 & 1.9044 \\
\hline 22 & 40 & 56 & 31 & 7 & 1 & - & & & & & & 135 & 278 & $2 \cdot 0593$ \\
\hline 23 & 35 & 54 & 28 & 12 & - & 1 & & & & & & 130 & 281 & $2 \cdot 1615$ \\
\hline 24 & 24 & 30 & 42 & 13 & 1 & 一 & 1 & 1 & & & & 112 & 282 & $2 \cdot 5179$ \\
\hline 25 & 25 & 54 & 27 & 12 & 3 & 2 & - & - & & & & 123 & 289 & $2 \cdot 3496$ \\
\hline Total (21-25) ... & 175 & 248 & 154 & 48 & 5 & 4 & 1 & 1 & & & & 636 & 1,389 & $2 \cdot 1840$ \\
\hline 26 & 10 & 28 & 26 & 18 & 7 & 2 & - & - & & & & 91 & 263 & $2 \cdot 8901$ \\
\hline 27 & 9 & 29 & 29 & 25 & 7 & 2 & 2 & 1 & & & & 104 & 323 & $3 \cdot 1058$ \\
\hline 28 & 11 & 20 & 20 & 12 & 12 & 5 & 2 & 3 & - & 1 & & 86 & 297 & $3 \cdot 4535$ \\
\hline 29 & 5 & 11 & 13 & 17 & 12 & 12 & 3 & - & 1 & 1 & & 75 & 306 & $4 \cdot 0800$ \\
\hline 30 & 1 & 13 & 14 & 15 & 16 & 10 & 4 & - & 1 & - & 1 & 75 & 319 & $4 \cdot 2533$ \\
\hline Total (26-30) .. & 36 & 101 & 102 & 87 & 54 & 31 & 11 & 4 & 2 & 2 & 1 & 431 & 1,508 & $3 \cdot 4988$ \\
\hline 31 & 4 & 5 & 13 & 10 & 11 & 6 & 4 & 2 & 1 & - & - & 56 & 237 & $4 \cdot 2321$ \\
\hline 32 & 3 & 11 & 13 & 14 & 3 & 4 & 5 & 1 & - & 1 & - & 55 & 212 & $3 \cdot 8545$ \\
\hline 33 & 2 & 7 & 8 & 10 & 7 & 4 & 6 & 1 & - & 1 & - & 46 & 199 & $4 \cdot 3261$ \\
\hline 34 & 2 & 3 & 6 & 7 & 3 & 3 & 2 & - & 2 & 3 & - & 31 & 149 & $4 \cdot 8065$ \\
\hline 35 & 5 & 一 & 5 & 5 & 7 & 4 & 3 & 1 & - & 1 & 1 & 32 & 149 & $4 \cdot 6563$ \\
\hline Total (31-35) $\ldots$ & 16 & 26 & 45 & 46 & 31 & 21 & 20 & 5 & 3 & 6 & 1 & 220 & 946 & $4 \cdot 3000$ \\
\hline 36 & - & 4 & 7 & 4 & 5 & 5 & 1 & 2 & 3 & 2 & & 33 & 170 & $5 \cdot 1515$ \\
\hline 37 & - & 5 & 4 & 5 & 2 & 7 & 4 & - & 2 & - & 1 & 30 & 153 & $5 \cdot 1000$ \\
\hline 38 & - & 一 & 4 & 6 & 7 & 2 & 3 & 2 & 2 & - & - & 26 & 138 & $5 \cdot 3077$ \\
\hline 39 & - & 1 & 1 & 1 & 1 & 2 & 3 & 5 & - & - & - & 14 & 87 & $6 \cdot 2143$ \\
\hline 40 & 一 & 2 & 4 & 4 & 3 & 2 & 1 & 3 & 1 & - & 1 & 21 & 110 & $5 \cdot 2381$ \\
\hline Total $(36-40) \quad .$. & - & 12 & 20 & 20 & 18 & 18 & 12 & 12 & 8 & 2 & 2 & 124 & 658 & $5 \cdot 3065$ \\
\hline Total (Over 40) & - & 1 & 1 & 2 & 5 & 3 & 3 & 3 & 3 & 2 & 1 & 24 & 159 & $6 \cdot 6250$ \\
\hline Grand Total & 485 & 498 & 338 & 204 & 113 & 77 & 47 & 25 & 16 & 12 & 5 & 1,820 & 5,190 & $2 \cdot 8516$ \\
\hline
\end{tabular}

high ratio of O/A women for the group over 40 years of age.

A further indication of the difference in pregnancy experience in the two groups of women is to be found in the distribution of group $\mathbf{O}$ and $\mathbf{A}$ among women experiencing their first pregnancy compared with those who have experienced at least two. Both for the women of English name and for the total Perth sample there is a significant excess of group $\mathbf{O}$ women experiencing their first pregnancy. Table VII $A$ (overleaf) gives $\chi^{2}=5.336(0.02<P<0.05)$ and $\chi^{2}=4.795(0.02<P<0.05)$ respectively.

The same discrepancy is observable in Boorman's sample, more than the total excess of group $\mathbf{O}$ women being found among the primiparae (Table VII $B$, overleaf). The difference for Boorman's sample, however, is not significant. This may be due solely to sample size, but the relatively smaller number of multiparous women in the English study 
TABLE VLA

NUMBER OF Rh-POSITIVE WOMEN OF GROUP O AND GROUP A

\begin{tabular}{|c|c|c|c|c|c|c|c|}
\hline \multirow{2}{*}{\multicolumn{2}{|c|}{$\frac{\text { Women ... }}{\text { Blood Group }}$}} & \multicolumn{3}{|c|}{ Of English Name } & \multicolumn{3}{|c|}{ Total in Perth Sample } \\
\hline & & \multirow{2}{*}{$\frac{0}{405}$} & \multirow{2}{*}{$\frac{A}{385}$} & \multirow{2}{*}{$\frac{0 / A}{1 \cdot 052}$} & \multirow{2}{*}{$\frac{O}{452}$} & \multirow{2}{*}{$\frac{A}{432}$} & \multirow{2}{*}{$\frac{\mathrm{O} / \mathrm{A}}{1 \cdot 046}$} \\
\hline \multirow{6}{*}{$\begin{array}{c}\text { Age } \\
\text { Group }\end{array}$} & 20 and under & & & & & & \\
\hline & $21-25$ & 677 & 636 & 1.064 & 801 & 773 & 1.036 \\
\hline & $26-30$ & 444 & 431 & $1 \cdot 030$ & 544 & 526 & 1.034 \\
\hline & $31-35$ & 218 & 220 & 0.991 & 255 & 262 & 0.973 \\
\hline & $36-40$ & 147 & 124 & $1 \cdot 185$ & 177 & 149 & $1 \cdot 188$ \\
\hline & Over 40 & 39 & 24 & $1 \cdot 625$ & 44 & 29 & $1 \cdot 517$ \\
\hline \multicolumn{2}{|c|}{ Total All Ages } & 1,930 & 1,820 & $1 \cdot 060$ & 2,273 & 2,171 & $1 \cdot 047$ \\
\hline
\end{tabular}

TABLE VIB

NUMBER OF WOMEN IN BOORMAN'S SAMPLE

\begin{tabular}{|c|c|c|c|c|}
\hline Blood Group & .. & o & $\mathbf{A}$ & O/A \\
\hline \multirow{6}{*}{$\begin{array}{l}\text { Age } \\
\text { Group }\end{array}$} & 14-19 & 40 & 35 & $1 \cdot 143$ \\
\hline & $20-29$ & 487 & 490 & 0.994 \\
\hline & $30-34$ & 185 & 187 & 0.989 \\
\hline & $35-39$ & 107 & 114 & 0.939 \\
\hline & $40-49$ & 53 & 30 & $1 \cdot 767$ \\
\hline & Not Known & 20 & 16 & $1 \cdot 250$ \\
\hline All Ages & .. & - 892 & 872 & $1 \cdot 023$ \\
\hline
\end{tabular}

TABLE VII $A$

NUMBER OF Rh-POSITIVE GROUP O AND A WOMEN EXPERIENCING THEIR FIRST PREGNANCY COMPARED WITH WOMEN EXPERIENCING SECOND PREGNANCY OR HIGHER

\begin{tabular}{|c|c|c|c|c|c|c|c|c|c|}
\hline \multirow{3}{*}{\multicolumn{2}{|c|}{$\begin{array}{l}\frac{\text { Women }}{\text { Pregnancy }} . . \\
\text { Blood Group .. }\end{array}$}} & \multicolumn{4}{|c|}{ Of English Name } & \multicolumn{4}{|c|}{ In Total Perth Sample } \\
\hline & & \multicolumn{2}{|c|}{ First } & \multicolumn{2}{|c|}{$\begin{array}{c}\text { Second or } \\
\text { Higher }\end{array}$} & \multicolumn{2}{|c|}{ First } & \multicolumn{2}{|c|}{$\begin{array}{l}\text { Second or } \\
\text { Higher }\end{array}$} \\
\hline & & $\mathbf{O}$ & $\mathbf{A}$ & $\mathbf{O}$ & $\mathbf{A}$ & $\mathbf{O}$ & $\mathbf{A}$ & $\mathbf{O}$ & $\mathbf{A}$ \\
\hline \multirow{6}{*}{$\begin{array}{r}\text { Age } \\
\text { Group }\end{array}$} & $\begin{array}{l}20 \text { and } \\
\text { under }\end{array}$ & 290 & 258 & 115 & 127 & 324 & 291 & 128 & 141 \\
\hline & $21-25$ & 215 & 175 & 462 & 461 & 260 & 228 & 541 & 545 \\
\hline & $26-30$ & 56 & 36 & 388 & 395 & 80 & 58 & 464 & 468 \\
\hline & $31-35$ & 15 & 16 & 203 & 204 & 24 & 18 & 231 & 244 \\
\hline & $36-40$ & 3 & - & 144 & 124 & 6 & 4 & 171 & 145 \\
\hline & Over 40 & 1 & - & 38 & 24 & 1 & - & 43 & 29 \\
\hline \multicolumn{2}{|c|}{ All Ages } & 580 & 485 & 1,350 & 1,335 & 695 & 599 & 1,578 & 1,572 \\
\hline
\end{tabular}

TABLE VIIB

BASED ON BOORMAN (1950)

\begin{tabular}{ll|c|c|c|c}
\hline Women ... &.. & \multicolumn{2}{|c|}{ Primiparae } & \multicolumn{2}{c}{ Multiparae } \\
\hline Blood Group &.. & O & A & O & A \\
\hline All Ages ... &.. & 514 & 482 & 378 & 390 \\
\hline
\end{tabular}

is undoubtedly of importance in masking any effect of birth rank.

\section{MisCARRIAGeS AND STILlBIRTHS}

The information relating to the number of miscarriages and stillbirths is unreliable as far as previous pregnancies are concerned. Women are asked to record any miscarriages and stillbirths experienced previously when first attending the prenatal clinic: confusion over the nature of miscarriages and stillbirths is not uncommon, and miscarriages in particular are likely to be understated in some cases, and overstated in others. The available information for $\mathrm{Rh}$-positive women of English name of the groups $O$ and $A$ in our sample is presented in Table VIII. The overall miscarriage and stillbirth frequency is identical for groups $\mathrm{O}$ and $\mathrm{A}$ women, and no significant difference by age can be demonstrated. If miscarriages and stillbirths are removed from the sample the number of live births

TABLE VIII

TOTAL NUMBER OF STATED MISCARRIAGES AND STILLBIRTHS EXPERIENCED BY WOMEN Rh-POSITIVE OF ENGLISH NAME

\begin{tabular}{|c|c|c|c|c|c|c|c|c|}
\hline \multirow{2}{*}{\multicolumn{2}{|c|}{$\begin{array}{l}\text { Experience } . \\
\text { Blood Group }\end{array}$}} & \multirow{2}{*}{$\frac{\cdots}{\cdots}$} & \multicolumn{2}{|c|}{ Miscarriage } & \multicolumn{2}{|c|}{ Stillbirth } & \multicolumn{2}{|c|}{$\begin{array}{r}\text { Miscarriage } \\
\text { + Stillbirth }\end{array}$} \\
\hline & & & 0 & $\mathbf{A}$ & 0 & $\mathbf{A}$ & 0 & $\mathbf{A}$ \\
\hline \multirow{6}{*}{$\begin{array}{r}\text { Age } \\
\text { Group }\end{array}$} & \multicolumn{2}{|c|}{20 and under } & 21 & 14 & 10 & 10 & 31 & 24 \\
\hline & \multicolumn{2}{|c|}{$21-25$} & 71 & 72 & 23 & 29 & 94 & 101 \\
\hline & \multicolumn{2}{|c|}{$26-30$} & 88 & 102 & 22 & 26 & 110 & 128 \\
\hline & \multicolumn{2}{|c|}{$31-35$} & 48 & 48 & 26 & 27 & 74 & 75 \\
\hline & \multicolumn{2}{|c|}{$36-40$} & 44 & 22 & 16 & 15 & 60 & 37 \\
\hline & \multicolumn{2}{|c|}{ Over 40} & 13 & 9 & 10 & 5 & 23 & 14 \\
\hline \multicolumn{3}{|l|}{ All Ages } & 285 & 267 & 107 & 112 & 392 & 379 \\
\hline
\end{tabular}

per woman in groups $\mathbf{O}$ and $\mathrm{A}$ follows the same distribution as that previously described for total pregnancies.

\section{Discussion}

The selective loss of $\mathrm{A}$ children to group $\mathrm{O}$ mothers in the mating group O-mother : A-father demonstrated by Waterhouse and Hogben (1947), should result in an apparent reduction of the average number of pregnancies with increasing age in all group $\mathbf{O}$ women unless some form of compensation occurs. The present analysis of total pregnancy experience for $\mathrm{Rh}$-positive women of groups $\mathbf{O}$ and $\mathbf{A}$ in a socially homogeneous maternity hospital sample suggests that at least one such compensatory mechanism may be operative. 
The observed series for the difference in the average number of pregnancies with age between women of group $\mathbf{O}$ and group $\mathrm{A}$ could result from the operation of several factors:

(a) Group $\mathrm{O}$ women in compatible mating groups have an innately higher fertility than group A women.

(b) Group $\mathrm{O}$ women in incompatible mating groups prolong their attempts to have children, and meet with greater success above the age of 35 .

(c) Group A women also suffer from a reduction in fertility, starting at a later age than in women of group $\mathrm{O}$ but becoming relatively more severe by the age of 40 .

These three alternatives are all capable of explaining the phenomenon. At the present time the evidence favours the hypothesis that group $O$ women in compatible mating groups have an innately higher fertility than women of group A. In the study of Waterhouse and Hogben the average number of children in families where the mother is group $\mathbf{O}$ $(3 \cdot 38)$ is identical with that for families where the mother is group A $(3 \cdot 37)$. But it is much higher in $\mathrm{O} \times \mathrm{O}$ families (3.46) than in A $\times \mathrm{A}$ families (3.17). The investigation of Boorman (1950) lends further indirect support to the view that group $O$ women are innately more fertile than group $A$ women unless married to a group A husband. Women under 20 years of age who are classed as incompatible for A-B-O groupings, i.e. mainly group $\mathrm{O}$ women, on the basis of the blood group of their last child have experienced slightly more pregnancies than women classed as compatible $(1.43$ as against 1.05$)$. But the incompatible group, where the incompatible antigen is group A, suffer a marked deficiency in child-bearing above the age of 20 compared with the compatible group, the difference increasing steadily. At age of 40-49 the respective figures are 2.91 and $3 \cdot 86$. Finally, in the present series, group $O$ mothers experience a higher number of pregnancies under age 19 than do group A mothers. This excess occurs before the effects of incompatibility have become apparent and probably represents a real excess on the part of group $\mathrm{O}$ women.

If this excess fertility of group $\mathrm{O}$ women in compatible matings is accepted, the following sequence of events would satisfy the observed facts.

Mothers of group $\mathbf{O}$ and group $\mathrm{A}$ occur in the total sample in the same proportions as do such women in the general population (Bryce and others, 1950).

Group $\mathbf{O}$ mothers show a slight initial excess in number of pregnancies experienced.

Some group $\mathrm{O}$ mothers belong to incompatible mating groups, the largest of these being incompatible for the $\mathrm{A}$ antigen (44 per cent. of all $\mathrm{O}$ mothers).
These women have a progressive reduction in relative fertility compared with group A women, so that, not only are there proportionately fewer women of group $\mathrm{O}$ in the sample between ages 25 and 35 , but each of them experiences fewer pregnancies on the average. One hundred group $\mathrm{O} R \mathrm{Rh}$-positive women aged $26-35$ have on the average 36 children fewer than 100 group A Rh-positive women of the same age. The discrepancy would be more marked probably if incompatible group $\mathbf{O}$ women only were included.

Above the age of 35 women of group A tend to complete their families more quickly than the group $\mathbf{O}$ women in the compatible class, who continue to bear children past the age of 40 more frequently than do women of group $A$. In the Perth sample studied here 100 group $O \mathrm{Rh}$-positive women above the age of 35 have on the average sixteen more children than $\mathbf{1 0 0}$ group $\mathrm{A}$ Rh-positive women of the same age.

This excess fertility of group $\mathbf{O}$ women in compatible mating groups could explain the replacement of O-genes lost through the selective elimination of heterozygous children in the mating group O-mother : A-father. It could not explain, however, the relacement of an equal number of A-genes lost at the same time. Further studies with larger samples to enable the accurate assessment of the contribution in other mating groups involving phenotypes $B$ and $A B$ may reveal the source of this replacement through the operation of a similar compensatory mechanism involving $B$ and $A B$ matings with women of group $A$. The excess of AB mothers noted by Bryce and others (1950) may play a part in this replacement.

\section{SUMMARY}

(1) Data are presented on the A-B-O and Rh blood groups, age, and pregnancy experience of women admitted to a large maternity hospital in Australia during the years 1948-51.

(2) A detailed analysis of the material relating to $\mathrm{Rh}$-positive women of English name is given.

(3) Women of blood groups $\mathrm{O}$ and $\mathrm{A}$ exhibit a differential pregnancy experience with age. In the earliest age groups, group $O$ women have had slightly more children than group A women. Between 25 and 35 years of age, however, group $O$ women experience fewer pregnancies than those of group $\mathrm{A}$, the position becoming reversed above the age 35. Orthogonal polynomials have been fitted to the differences in average number of pregnancies between women of groups $\mathbf{O}$ and $\mathrm{A}$ for each year of age from 16-40. The result shows the trend to be highly significant. 
(4) The number of group $O$ women in the sample follows the same trend, there being proportionately fewer women of group $O$ between 25 and 35, and an excess above age 35 , which is most marked above age 40 .

(5) There is a significant excess of group 0 women who are experiencing their first pregnancy.

(6) A hypothesis is advanced which suggests that women of group $\mathbf{O}$ in a compatible mating group are on the average more fertile than either women of group $\mathrm{O}$ in an incompatible mating group or women of group $\mathbf{A}$.

We are indebted to Matron Walsh and the staff of the King Edward Maternity Hospital, Perth, for granting facilities to collect the data presented here. We are also indebted to Dr. W. A. Young of the West Australian Department of Public Health, and to Drs. G. A. Kelsall and J. Watson for their encouragement and help.

\section{REFERENCES}

Boorman, K. E. (1950). Ann. Eugen., Camb., 15, 120.

Bryce, L. M., Jakobowicz, R., McArthur, N., and Penrose, L. S. (1950). Ibid., 15, 271

Hart, E. W. (1944). Ibid., 12, 89.

Landsteiner, K., and Wiener, A. S. (1940). Proc. Soc. exp. Biol., N.Y., 43, 223 .

Levine, P. (1943). J. Hered., 34, 71

, Burnham, L., Katzin, E. M., and Vogel, P. (1941). Amer. J. Obstet. Gynec., 42, 925 .

Race, R. R., and Sanger, R. (1950). "Blood Groups in Man." Blackwell, Oxford.

Roberts, J. A. F. (1948). Ann. Eugen., Camb., 14, 109.

Waterhouse, J. A. H., and Hogben, L. (1947). British Journal of aterhouse, J. A. H.,

Social Medicine, 1,1 .

Wiener, A. S. (1943).

Thomas, Springfield. 